\title{
POSSÍVEIS RAÍZES INDÍGENAS DE UMA DANÇA POPULAR
}

\author{
Antonio Candido \\ (Universidade de São Paulo)
}

O cururu é dança praticada pelos caboclos de São Paulo, Goiás e Mato Grosso. Em nosso Estado, não se encontra por tôda parte, mas em certas zonas velhas - notadamente a periferia da Capital e a Baixa Scrocabana. Fora daí, ocorrerá por difusão recente, e tudo leva a crer que se tenha formado na primeira das áreas mencionadas.

As suas formas são várias, mas essencialmente consta de uma dança rodeada em que tomam parte via de regra apenas os homens; de uma saudação aos presentes; uma louvação aos santos e finalmente desafios em que os contendores - sempre dançando - propõem uns aos outros problemas, de fundo religioso ou profano, visando derrotar o adversário e exaltar a própria pessoa. Num trabalho já bastante adiantado, procuro estudar a sua função social na sociedade caipira de hoje, sob o impacto da urbanização. ${ }^{1}$ Neste, desejo debater alguns pontos relativos à sua origem. Devo portanto deixar claro que se trata de uma tentativa de reconstituição de caráter bastante conjectural. Tôdas as vêzes que não temos dados seguros para conhecer as raízes de um traço de cultura, cabe a aventura intelectual da suposição, contanto que fundamentada em documentos idôneos e desenvolvida segundo os princípios lógicos da disciplina a que se liga o estudo. Assim, estaremos perto da verossimilhança, que é uma forma modesta e por vêzes frutuosa de verdade. O que importa é não confundir os planos nem querer dar a tentativas desta espécie o caráter da certeza.

E se não couberem num estudo sôbre função social do cururu, caberão sem dúvida como investigação complementar.

Nas poucas mas substanciosas referências que deixou sôbre o cururu, Mário de Andrade, prosseguindo afirmações de Couto de Magalhães, firmou um ponto de vista que pode ser considerado como síntese dos indícios fornecidos pela tradição e verossimilhança: "Entre as nossas formas coreográficas, uma das mais espalhadas é o Cateretê ou a Catira, dança de nome tupi. Anchieta para catequizar os selvagens já se aproveitara dela, parece, deformando-lhe os textos no sentido da Religião Católica . Caso mais indiscutível ainda dessa fusão ameríndio-jesuítica é o do Cururu. Em certas festas populares, religioso-coreográficas, tais como a dança de São Gonçalo e a dança de Santa Cruz, pelo menos nos arre- 
dores de São Paulo, após cada número do cerimonial, dença-se um Cururu. Ora, os processos coreográficos desta dança têm um tal e tão forte sabor ameríndio, pelo que sabemos de danças brasílicas com a cinematografia atual, que não hesito em afirmar ser o Cururu uma primitiva dança ameríndia, introduzida pelos jesuítas nas suas festas religiosas, fora (e talvez dentro) do tempo. E êsse costume e dança permaneceram até agora."

Esta opinião permanece entre os folcloristas, e não há motivo para ser contestada. Resta todavia esclarecer os problemas relativos a como se teria dado a fusão referida por Mário de Andrade, e sem isto não se poderá cientificamente aceitar a sua opinião. Entre tais problemas estão os seguintes:

1 - Haveria uma dança indígena de que o cururu derivasse diretamente? Quais as suas características?"3

2 - De que modo os catequistas teriam influído na sua incorporação à cultura néo-brasileira?

3 - Por que é o cururu encontrado apenas em áreas de povoamento paulista?

4 - Há elementos para avaliar a sua antigüidade, emergência, características iniciais, manifestações e modificações?

Quando não a resposta, pelo menos a discussão dêstes tópiccs pode ajudar-nos a esclarecer o problema das origens, que não são des-sprezíveis para o entendimento conveniente da sua função atual.

1.

Como se sabe, cururu é "nome genérico do sapo na língua tupi" está presente em mitos sôbre a origem do fogo entre diferentes tribos dêste grupo, bem como noutras que the sofreram a influência.

No primeiro caso encontramos o Chiriguano, Apapokuva, Guaraní do litoral paulista, Tapirapé, Chiripá, Guaraiu, Guajajara, Mbyá-Guarani, ${ }^{5}$; no segundo, os Chané e Tapieté ${ }^{6}$. Não sei se há possibilidade de explicar pelo contacto cultural o mito análogo dos Tumupasa, da BoJívia Oriental, e o dos Karajá, únicos exemplos que pude encontrar de sapo doador ou preservador do fogo fora das culturas Tupi ou tupinizadas, - é verdade que numa investigação sumária. ${ }^{7}$

A propósito dêste assunto, escreve Herbert Baldus: "O roubo do fogo por animais é um motivo muito espalhado na América do Sul. Ora é a raposa a ladra da faísca, ora o sapo. O sapo sempre o é nas tribos da grande família lingüística dos Tupi. Que êle haja sido escolhido para tal papel é muito compreensível, porque, como se sabe, êste animal tem a capacidade singular de engulir coisas ardentes, como cigarros e brasas, talvez porque os tome por pirilampos." 
Na representação dramática de tais mitos, podem ocorrer verdadeiras "danças do sapo", en que os dançadores refazem o processo mítico e encarnam o batráquio dispensador do fogo: "Por fim, seja citada ainda a naração de uma representação do roubo do fogo numa dança de Kururu na tribo tupí dos Guajejara no Rio Grayahú no Maranhão (Heinrich Snethlage: "Meine Reise durch Nordostbrasilien", Journal für Ornithologie 75, Berlin, 1927, pp. 468-469): Recomeçou o canto; quando se tornou mais alto, o chefe da tribo levantou-se, dançou alguns passos e sentou-se novamente. Então trouxeram-lhe um gigantesco cachimbo no qual êle chupou algumas vêzes. Mais fogosamente repetiu a dança, enquanto eu aproveitava a ocasião para experimentar o pito. Não me dei muito bem com a cachimbcda, porque os nervos da cavidade bucal me ficavam imediatamente afetados. A cada intervalo do baile punha-se o chefe e cachimbar. Que isto the era necessário evidenciou-se depois. Ateou-se um fogo ao redor do qual os rapazes morenos pulavam em estado de embriaguez completa. De repente o chefe acocorou-se e pôs-se a saltitar pelo fogo a soltar o $h u, h u$, $h u$ do sapo. Depois tomou uma brasa e pondo-se a assoprá-la, enguliu-a de vagar. Isso foi o ponto culminante đc baile, mas não o único. A dança durou, quase sem interrupção, tôda a noite. E sempre se repetia a cena do engulir da brasa." "9

Entre tribos Tupi do Amazonas, Barbosa Rodrigues registra a "dança do cururu", acompanhada de um canto cujas primeiras palavras são: "Yá munhan moracé, cururú, cururú", ou seja, "vamos dançar, sapo".10

Resta saber se em tribos não-Tupi encontramos práticas seme1hantes. No seu Folk-Lore, diz João Ribeiro: “...entre os borórós de Mato Grosso (pratica-se) a cerimônia ritual e funerária que chamam bacururú e que é celebrada entre clamores e algazarra grande. As palavras bacururú e cururú têm radicais comuns. Não é inverossímil que dos borórós tenha vindo o nome da dança do cururú."11 Para o ilustre escritor esta só existia em Mato Grosso, daí a fantástica derivação que irnaginou. Cururu é, como vimos, palavra tupi, e nada tem a ver com a referida cerimônia, cujo nome verdadeiro é "róia Kurireu", ou "canto grande", iniciada com uma imprecação em que surge o nome de um dos heróis civilizadores dos Borôro, os gêmeos míticos Bakororo e Itubore:

"a-a o-o Bakororo Kai re". ${ }^{12}$

A transcrição defeituosa de João Ribeiro serviu de asa à sua imprudente conclusão.

Max Schmidt, no comêço dêste século, encontrou entre os Guató, no sul de Mato Grosso, larga prática do cururu; recentemente, Edmund Döppenschmidt encontrou-a, em região próxima desta, entre os Kinikinau do rio Taquari. ${ }^{13} \mathrm{Em}$ ambos os casos, não pode haver a menor dúvida de que se trata de um traço tomado à cultura cabocla, e integrado em cada tribo de acôrdo com a sua respectiva organização. 
Resulta, pois, que não encontramos "danças do sapo" em tribos nãotupi. E se, como pretendeu João Ribeiro, houvermos de supor um fenômeno de difusão cultural, deveremos focalizar de preferência as áreas em que foi massiço o contacto entre colonizadores e povos do grupo Tupi-Guarani - fato ocorrido inicialmente, e muito mais, nas regiões litorâneas do que no atual Mato-Grosso.

Fora das culturas tribais, não sei de referência expressa ao cururu no Brasil setentrional, além de informação oral de Herbert Baldus, que presenciou certa vez, no Norte de Goiás, uma dança com êste nome, por sertanejos vindos do Norte ou do Nordeste. Dançavam-na em roda, busto inclinado para a frente, pernas flectidas para os lados, numa coreografia imitativa dos pulos de sapo. Neste caso (não sei até que ponto representativo de prática generalizada e tradicional), estaríamos ante uma herança indígena de relativa pureza, ligada possivelmente a práticas rituais de origem tupi, no gênero da que descreveu Snethlage, e reinterpretada em têrmos recreativos pelos caboclos que Baldus observou. ${ }^{14}$

A reinterpretação, aliás, deve ser encarada como conceito básico no caso de ter havido difusão. Com efeito, dentro da melhor verossimilhança, esta se deu por intermédio da catequese jesuítica, tendo se desenvolvido em São Paulo, onde os inacianos mantiveram contacto prolongado com mais de uma tribo Tupi (mormente Tupiniquim, Tupinambá e Carijó), podendo imaginar-se um conjunto de condições favoráveis à reinterpretação de dansas indígenas no sistema sócio-cultural das aldeias de catecúmenos.

Resta, porém, o problema dos Guaianá, que habitavam partes consideráveis do litoral e da região de Serra-acima, inclusive o local da aldeia de Piratininga. Se eram Tupi, ou Kaingáng, não saberíamos decidir: o que não padece dúvida, porém, é que, a ser verdadeira a segunda hipótese, eram índios tupinizados, na língua, nos costumes e nas alianças. ${ }^{15}$

Aliás, não seriam os Guaianá de Piratininga os únicos Kaingáng permeados de cultura Tupi-Guarani, visto como Azara encontrou outros, nas mesmas condições, pela zona hoje fronteiriça do Paraná com a República Argentina. E a sua assimilação foi tão acentuada, que negavam qualquer vínculo com a nação de origem. ${ }^{16}$ A sua presença em São Paulo não seria, portanto, impecilho ou suspensão do contacto extenso do conquistador e do catequisador com as populações e a cultura Tupi.

\section{2 .}

Não padece dúvida a circunstância de os jesuítas haverem aproveitado cantos e danças dos índios para propiciá-los à compreensão e aceitação mais pronta da doutrina cristã. As festas religiosas são, aliás, intercomunicáveis, e um dos trabalhos prediletos de mitólogos e folcloristas é justamente pesquisar as sobrevivências pagãs nos festejos cris- 
tãos. Nem por isso foram os padres compreendidos desde logo pelas autoridades eclesiásticas, que vislumbraram mancha de paganismo e desvio da boa norma doutrinária nessas tentativas inteligentes de facilitar a aculturação religiosa. Nessas e em outras mais ousadas, - como a confissão por intermédio de intérpretes, proibida a Nóbrega pelo Bispo da Bahia em 1552, mas que continuou sendo praticada, como vemos em Anchieta e Cardim, que a ela se refere com louvor trinta e poucos anos depois. ${ }^{17}$ A mesma proibição estendeu-se ao referido aproveitamento de danças e cantigas: "Os meninos desta casa costumavam cantar, pelo mesmo tom dos Índios, e com seus instrumentos, cantigas na língua, em louvor de Nosso Senhor com que se muito atraíam os corações dos índios; e assim alguns meninos da terra traziam o cabelo cortado à maneira dos Índios, que têm muito pouca diferença do nosso costume, e faziam tudo para a todos ganharem. Estranhou-o muito o Bispo, e na primeira pregação falou nos costumes dos gentios muito largo, por donde todo o auditório o tomar por isso e foi assim, porque a mim o repreendeu mui àsperamente, nem aproveitou escusar-me que não eram ritos nem costumes dedicados a ídolos, nem que prejudicassem a fé católica."18

A atitude do Bispo não revela apenas incompreensão e pirraça, mas significa também compreensível mecanismo de defesa, ou preservação de padrões postos à prova ao contacto de cultura exótica, num processo aculturativo que os jesuítas procuravam dirigir com certa tolerância. E na verdade, o desenvolvimento da religião católica no Brasil deu lugar a fenômenos de acentuado sincretismo, em que a pureza das expectativas eclesiásticas foi muitas vêzes eclipsada por novas práticas e sentimentos, aberrantes, mas úteis à sua preservação nas novas populações aqui formadas. Foi o que sentiram os jesuítas, e o que explica a atitude de Manuel da Nóbrega expressa nesta carta.

Não se pode todavia dizer que tenham desejado conscientemeñte o que em seguida se verificou. Parece, pelo contrário, que compreendiam a adoção de práticas aborígenes como técnica provisória, para servir de passagem à perfeita identificação do índio catequizado com a cultura ocidental, pelo menos no que se refere à vida religiosa. ${ }^{19}$ Em face de índios integrados nas práticas religiosas, musicais e poéticas do colonizador, Fernão Cardim deixa claramente manifestar-se a satisfação de quem vê as coisas no pé em que se quis colocá-las: "Missa de canto d'órgão, oficiada pelos índios e outros cantores da Sé", ou "diálogo pastoril, em língua brasílica, portuguêsa e castelhana" ou "missa solene com diácono e sub-diácono, oficiada em canto d'órgão pelos índios, com suas frautas, cravo e descante", ou "uma dança de escudos à portuguêsa, fazendo muitos trocados e dançando ao som da viola, pandeiro e tambcril e flauta, e juntamente representavam um breve diálogo, cantando algumas cantigas pastoris." São êstes os casos que se enquadravam no comentário do Padre: "Tudo causava devoção debaixo de tais bosques, 
em terras estranhas, e muito mais por não se esperarem tais festas de gente tão bárbara." 20

Ao lado desta superimposição dos padrões portuguêses, conservavam-se em estado de pureza usos e práticas locais, como em certa festa ao Padre Visitador, onde os índios dançavam largamente à sua maneira, fazendo "seus trocados e mudanças com tantos gatimanhos e trejeitos, que é coisa ridícula." 21 Noutros casos, aparece o nítido encontro da tradição local com os novos padrões trazidos pela conquista e pela catequese. "Acabada a missa, houve procissão solene pela aldeia, com danças dos índios a seu modo e à portuguêsa (...) Era para ver, os novos critãos, e cristãs saírem das suas ócas como conumis, acompanhados de seus parentes e amigos, com sua bandeira diante e tamboril." 22

São aspectos do processo geral de aculturação. De um lado, os grupos indígenas incluíam na sua vida religiosa elementos tomados ao cristianismo; de outro, a catequese assumiu certos compromissos com a cultura local. Do primeiro caso, temos um exemplo expressivo em certas crises aculturativas, como a Santidade desenvolvida na Bahia em fins do século XVI, na qual se vê um movimento messiânico esposar formas cristãs deturpadas e misturadas a práticas autóctones. Foi o caso de um índio catequizado e ex-aluno dos Padres da Companhia, que se intitulou Papa, declarou uma índia encarnação da Mãe de Deus e estabeleceu o culto dum ídolo lítico, batizando o gentio e desenvolvendo um ritual - ao qual se incorporaram alguns brancos. ${ }^{23}$

Mais regular e normalmente, porém, deu-se o segundo caso, com incorporação de práticas mágico-religiosas do aborígene à sociedade formada pela catequese e a fusão de raças e culturas - quer como sobrevivência, a título de superstição, quer em certos casos, pela tolerância estratégica do catequista. Alguns dêstes chegaram a produzir literatura singela para dirigir e coordenar tal processo, como Anchieta e outros: "Nos primeiros tempos, os Padres, como S. Paulo, faziam-se tudo a todos para ganhar todos a Cristo. Reproduziam os gestos e músicas dos Índios; e, para industriar e animar os meninos, tocavam e, até alguma vez, dançavam com êles.

Tais danças tinham caráter semi-profano, semi-hierático. Na bagagem literária de Anchieta, ficaram-nos algumas letras para danças, incluídas em autos sacros ou destinadas a procissões ou festas familiares: Dança de dez meninos na recepção do Provincial Padre Beliarte; Dança que se fêz na procissão de São Lourenço de 12 meninos, etc. Também chegaram até nossos dias muitas cantigas, em tupi e português, que a gente cantava nas ıgrejas e pelas ruas e praças. Exibições coreográficas dêste gênero tornaram-se número obrigatório de tôdas as procissões. Acentuada, porém, a infiltração cristã, começaram a fazer-se "a seu modo e à portuguêsa", ou só "à portuguêsa". ${ }^{24}$ 
O fato é que tal se deu apenas na intenção dos padres. Para tanto, era preciso que se houvesse desenvolvido aqui uma sociedade de tipo estritamente português. Se encararmos o período colonial, sobretudo em lugares de vida rude e menor distância cultural entre as camadas da população, como a área paulista, veremos, em lugar disso, uma sociedade marcada pela mistura de raças e culturas, muito mais apegada, do que desejariam talvez os padres, àquelas práticas, ccrrespondentes às suas necessidades de integração. O compromisso que êles encaravam como ponte transitória, no dizer do seu historiador ${ }^{25}$, foi na realidade parte definitivamente incorporada à vida social do néo-brasileiro de $\mathrm{S}$. Paulo - e tal incorporação, valendo como prova do caráter aculturativo da nova sociedade, representa o que poderíamos definir como reação da necessidade organizatória, determinada pelas características estruturais e culturais Cesta sociedade, contra a superimposição da camada dominante européia. Depois foi-se processando a diferenciação entre um estrato superior (em que se conservaram melhor os padrões europeus, ou que se foi re-europeizando) e a massa caipira - onde se preservaram os traços característicos das fases iniciais da sociedadie paulista, meio portuguêsa, meio índia.

\section{3.}

Devemos agora indagar como se teria originado o cururu a partir das condições indicadas. Couto de Magalhães, como vimos, afirma taxativamente que era dança religiosa tupi, incorporada, como o cateretê, a certas festas religiosas. Infelizmente, ao descrever as danças dos índios, os cronistas poucas vêzes thes dão o nome, mas é possível, e mesmo provável, que, dada a importância do sapo nos mitos tupi sôbre a origem do fogo, muitas tribos desta família lingüística possuíssem danças de roda em. sua intenção, como as observadas por Barbosa Rodrigues e Snethlage. Tanto mais quanto sabemos que as imitações de animais eram freqüentes entre êles. ${ }^{26}$ Mesmo que não derive especificamente de um bailado homônimo, a designação the deve ter vindo dêle, seja por analogia no canto e na coreografia, seja porque, a certa altura, cururu tenha servido para - néo-brasileiro de denominação genérica das danças indígenas de roda, dentre as quais avultaria a representação do sapo em sentido mágico-religioso. A hipótese plausivel é que os padres e os índios ajustassem às festas católicas não só os passos e o canto, mas os demais elementos constitutivos das danças aborígenes, como são relatadas pelos cronistas: louvor de personagens sobrenaturais, relato de feitos, debate poético, oportunidade de afirmação pessoal. Só que o conteúdo foi substituído, aparecendo os santos, as virtudes, e nutrindo-se depois o tema do debate, o relato de feitos e a afirmação pessoal, dos elementos sugeridos pela nova situação, de que ia emergindo aos poucos a cultura caipira. Como foi 
praticado até há cerca de meio século de modo absoluto, e como ainda o podemos hoje vislumbrar em casos sobreviventes, o cururu corresponđe a essa constelação de elementos, transposta da sociedade tribal e reinterpretada em vista da integração de uma nova sociedade, não primitiva, mas rústica.

Registremos agora a ocorrência dos referidos elementos entre os Tupi. Dêles diz Léry: "Tout pres à pres l'un de l'autre, sans se tenir par la main ni sans se bouger d'une place, ains estans arrengez en rond, courbez sur le devant, guindans un peu le corps, remuant seulement la iambe \& le pied droit, chacun ayant aussi la main dextre sur ses fesses, $\&$ le bras \& la main gauche pendant, chantoyent \& dansoyent de cette façon". ${ }^{27}$ Segundo Cardim, "os seus bailos não são diferenças de mudança, mas é um contínuo bater de pés estando quedos, ou andando ao redor e meneando o corpo e cabeça, e tudo fazem por tal compasso, com tanta seriedade, ao som de um cascavel". ${ }^{28}$ Gabriel Soares confirma: "nos seus bailos não fazem mais mudança, nem mais continências que bater no chão com um só pé ao som do tamboril; e assim andam todos juntos à roda. . ."29

Dança rodeada, portanto, e compasso marcado com o pé - dois elementos coreográficos incorporados ao cururu. Nas suas formas arcaicas - como pude presenciar nos arredores de Cuiabá - cs cantadoresdançadores circulam ràpidamente, quase encostados um no outro, marcando o compasso por uma descaída uníssona do pé direito.

Mesmo considerando a hipótese de não serem do grupo Tupi os Guaianá de Piratininga, não haveria na sua cultura coreografia contraditória a esta. Segundo Metraux, os Kaingáng, entre os quais os inclui, dançavam "em dois círculos concêntricos à volta de fogueiras, os homens por dentro e as mulheres por fora. Um cantor, no centro, sacode o chocalho".30 Tal esquema foi encontrado por Barbosa Rodrigues entre os Tembé e, pouco mais ou menos, por Nimuendajú entre os Apiacá e os Parintintim, todos do grupo Tupi. ${ }^{31} \mathrm{E}$ sabemos que a dança cabocla do cururu podia tembém executar-se desta maneira em alguns casos - parecendo tudo isto confirmar que ela proveio de zona onde se dava contacto massiço de branco e índios Tupi ou tupinizados.

Quanto ao segundo elemento, sabemcs que êstes são apaixonados de canto e música. Ao fim da dança acima referida, Léry teve uma espécie de deslumbramento, ao ver o côro elevar "une telle melodie qu'attendu qu'ils ne sçavent que c'est de musique, ceux qui ne les ont ouys ne croiroyent iamais qu'ils s'accordassent si bien (...) i'eus lors... une telle ioie, que non seulement oyans les accords si bien mesurez d'une telle multitude, \& surtout pour la cadence \& le refrein de la balade... i'en demeuray tout ravi: mais aussi toutes les fois qu'il m'en ressouvient, le coeur m'en tressaillant, il me semble que ie les aye 
encore aux oreilles."32 "Os tupinambá se prezam de grandes músicos, - diz Gabriel Soares - e, ao seu modo, cantam com sofrível som, os quais têm boas vozes; mas todos cantam por um tom, e os músicos fazem mote de improviso, e suas voltas que acabam no consoante do mote; um só diz a cantiga, e os outros respondem com o fim do mote, os quais cantam e bailam juntamente em uma roda..."33 E Fernão Cardim: ". . bailam cantando juntamente, porque não fazem uma coisa sem outra (...) Guardam entre si diferenças de vozes em sua consonância, e de ordinário as mulheres levam os tiples, contraltos e tenores." 34 Modernamente, observaram Wagley e Galvão ser o canto a principal diversão dos Tapirapé, que dançam e cantam ao mesmo tempo; e que os Tenetehára são grandes amadores de música, da sua e da que aprendem com os caboclos, constituindo os cantos a base da sua vida estética. ${ }^{35}$

Quanto aos temas, "cantam em trova quantas façanhas e mortes tenham feito seus antepassados. Arremedam pássaros, cobras, e outros animais, tudo trovado por comparações, para se incitarem a pelejar. Estas trovas fazem de repente, e as mulheres são insignes trovadoras. Também quando fazem êste motim tiram um e um a terreiro, e ambos se ensaiam até que algum cansa, e logo the vem outro acudir. Algumas vêzes procuram de vir a braços e amarrar o contrário, e tudo isto fazem para se embravecer." 36

A análise dêste trecho nos permite discernir os seguintes elementos: 1) celebravam façanhas dos maiores; 2) inspiravam-se nos mitos de animais; 3) cantavam de improviso; 4) estabeleciam debates poéticos a ver quem levava a melhor (chegando algumas vêzes à luta corporal simulada); 5 ) daí resultava prestígio ao bom cantor. O processo de reinterpretação, dirigido pelos padres, atingiu alguns dêstes elementos, sendo outros atingidos pelo desenvolvimento ulterior. A celebração dos antepassados e seus feitos foi substituída pela dos santos e catequizadores, fixando-se na parte do cururu chamada louvação, que é a matriz das demais. Como se teria dado a passagem, podemos depreender dêstes trechos de Cardim: "Fomos em procissão até a igreja com uma dança de homens de espadas, e outras dos meninos da escola; todos iam fazendo seus ditos às santas relíquias." "Acabada a missa, houve procissão solene pela aldeia, com danças dos índios a seu modo e à portuguêsa; e alguns mancebos honrados também festejaram o dia dançando na procissão, e representaram um breve diálogo e devoto sôbre cada palavra da Ave Maria, e esta obra dizem compôs o padre Álvaro Lobo."34

No primeiro caso, temos o exemplo de uma 'ouvação espontânea, - os índios transferindo para as Santas Relíquias levadas pelo Visitador aquela celebração improvisada em que honravam os maiores. No segundo, temos o exemplo de uma louvação mais dirigida. Anchieta compreendeu o sentido adaptativo desta dualidade, e compôs não apenas au- 
tos elaborados, mas, também, coplas e poemas breves, a fim de não restringir demasiado as formas de ajustamento religioso aos tipos mais eruditos e, portanto, distantes da tradição tribal. ${ }^{38}$

O improviso, que permite ampliar a participação, pois nêle podem intervir os circunstantes, é também assinalado entre os Guaianá, que cantavam fatos e acontecimentos de circunstância, elemento importante no desenvolvimento do cururu, baseado em parte nesse aproveitamento poético do quotidiano. ${ }^{39} \mathrm{Nele}$ se encontra freqüentemente o fundamento do debate, - substância do canto. A reinterpretação de prática indígena semelhante explicaria satisfatòriamente certas características que não podem ser compreendidas à luz do desafio, como é praticado em Portugal e se transmitiu aos nossos cablocos. O desafio de cururu, na sua forma original, é peça integrante da dança e se enquadra numa estrutura poética mais complexa, precedido pela saudıção e a louvação, obedecendo além disso a certos limites de decôro devido ao teor religioso. Ora, a existência de uma polêmica nas danças tupi, claramente indicada pelo texto de Cardim, e transporta a um contexto religioso, em ligação a outros traços, no processo de reinterpretação, satisfaz mais cabalmente do que supô-la criunda do desafio português - que certamente interferiu no processo, mas não seria a raiz da prática. Entre as funções atribuíveis ao debate, prepondera, pelo que se depreende dos textos antigos e de atuais perquisas etnográficas, o prestígio resultante do bom cantador. "( . . ) são muito estimados entre êles os cantores, assim homens como mulheres, em tanto que se tcmam um contrário bom cantor e inventor de trovas, por isso que the dão a vida e não no comem nem. aos filhos. "40 "Entre êste gentio são os músicos mui estimados, e por onde quer que vão, são bem agasalhados, e muitos atravessaram já o sertão por entre seus contrários, sem lhes fazerem mal." 41 "Um indivíduo de boa voz e largo repertório de cantos é muito admirado pela comunidade." 42 "Os xâmanes são cbrigados a ter largo repertório de cantos (e...) uma boa voz é requisito para o xamanismo." 43

Numa cultura tôda permeada pela importância da música, do canto e da eloqüência, é normal que a preeminência nestas atividades importasse em aquisição ou refôrço da posição social do indivíduo. A afirmação dêste prestígio abria possibilidade para uma segunda etapa na aquisição de status - ou iseja a oportunidade de imp r mais fàcilmente ao grupo audiência à auto-vallcrização, que não deixava de o ser, mesmo quando expressa em têrmos coletivos: "Os índios se reuniram, formaram uma grande roda e colocaram dentro os prisioneiros. Esstes deviam todos juntos cantar e matraquear, com os ídolos, os maracás. Depois, um após outro, discursavam com audácia, dizendo: "Sim, partimos, ccmo fazem os homens corajosos, a fim de a vós, nosso inimigo, aprisicnar e comer. Mas então tivestes a supremacia e nos capturastes. Isso não importa. Guerreiros valorosos morrem na terra dos seus inimigos. E a 
nossa terra ainda é grande. Os nossas nos vingarão em vós." Ao que respondiam os outros: "Vós já exterminastes muitos dos nossos. Tal queremos vingar em vós." "E sem falta isão mui eloqüentes e se prezam a kguns tanto disto que, da prima noite até pela manhã, andam pelas ruas e praças pregando, excitando os demais à paz ou à guerra, ou trabalho, ou qualquer outra coisa que a ocasião lhes oferece, e, entretanto que um fala, todos mais calam e ouvem com atenção." 45 De certos textos quinhentistas ressalta claremente a correlação da liderança e da eloqüência: "Em cada oca destas há sempre um principal a que têm alguma maneira de obediência. Este exorta a fazerem suas roças e mais serviços, etc., excita-os à guerra; e the têm em tudo respeito (...) Entre êstes seus principais $ı$ u pregadores, há alguns velhos antigos de grande nome e autoridade entre êles, que têm fama por todo o sertão, trezentas e quatrocentas léguas e mais. Estimam tanto um bom língua que line chamam o senhor da fala. Em sua mão tem a morte e a vida, e os levará por onde quiser sem ccntradição." 46 "Fazem muito caso entre si, como os Romanos, de bons línguas e thes chamam senhores da fala, e um bom língua acaba com êles quanto quer e lhes fazem nas guerras que matem ou não matem e que vão a uma parte ou à outra, e é o senhor de vida e morte e ouvem-no tôda uma noite e às vêzes também o dia, sem dormir nem comer e para experimentar se é bom língua e eloqüente, se põem muitos com êle tôda uma noite para $o$ vencer e cañar, e se não o fazem, o têm por grande homem e língua. Por isso há pregadores entre êles muito estimados que os exortam a guerrear, matar homens $e$ fazer outras façanhas desta sorte." 47

Os textos citados permitem estabelecer a importância da capacidade poética e oratória como técnica de aquisição de status e elemento poncerável no estabelecimento da liderança numa cultura em que, já mencionamos, tais capacidades se ligam a atividades altamente significativas.

4.

As danças das tribos tupi apresentam, pois, um conjunto de elementos que foram integrados na dança caipira do cururu, segundo um processo de reinterpretação orientado por duas fôrças ora complementares, ora convergentes, ora divergentes: de um lado, a pressão cultural exercida por intermédio dos jesuítas, sob a forma de catequese religiosa; de outro, as necessidades de organização manife tadas pela sociedade néo-brasileira, oriunda do contacto racial e cultural.

A pressão cultural exercida, no sentido de incorporá-la aos padrões do conquistador português, manifesta-se, no caso presente, pela estratégia "de ponte" do missionário, mais hábil do que se mostrou gera!mente - administrador. As necessidades da nova sociedade motivaram fre- 
qüentemente uma dissolução dos elementos puramente europeus, conformando-os ao meio, quando não rejeitando-os. Por outro lado, os elementos tomadas às culturas aborígenes sofreram tratamento análogo.

Nos lugares onde se estabeleceu, desde o início, um estrato social dominante e ligado intimamente à tradição do Reino (como foi o caso da Bahia e de Pernambuco, devido principalmente a fatôres de ordem político-administrativa), a cultura portuguêsa pôde desde logo transplantar-se. A consequêencia foi o desenvolvimento por assim dizer de dois planos culturais, o português e o sincrético (êste, acentuado logo depois na faixa litorânea pela contribuição africana), estabelecendo-se uma distância apreciável entre a camada dominante e a camada dominada, tanto no plano estrutural quanto no da cultura, - mesmo levada em conta a influência dos povos de côr na vida de família, estudada por Gilberto. Freyre.

Em São Paulo, todavia, área maìi à margem da administração metropolitana, não se diferenciaram tão nìtidamente estratos sociais, nem modos de vida. A superposição de camadas profundamente diversas só se terá processado aqui a partir do século XVIII, e principalmente XIX. Característico, neste sentido, é o effôrço de Pedro Taques para discriminar na rude balbúrdia dos cruzamentos mamelucos as linhas de uma aristocracia de sangue, que só com a ascenção econômica do café iria adquirir auto-ccnsciência equivalente à que tiveram os proprietários baianos e pernambucanos desde os primeiros séculos da colonização.

Em São Paulo, pois, houve condiçc̃es favoráveis e duradouras para a mistura de traços e a formação de uma sociedade relativamente homogênea, onde o fazendeiro, o preador de índios, o diescobridor de ouro, o morador, o agregado, estavam muito mais perto um do outro, do ponto de vista racial, cultural e social, do que cs latifundários nordestinos dos seus dependentes, ou dos comerciantes da cidade. Daí a permanência de traços aborígenes incorporados desde logo e fundidos de maneira harmoniosa na cultura do conquistador. Daí a dificuldade encontrada quando queremos discernir as articulações dêsse processo. Será possível conjecturar até que ponto o cururu representa uma difusão mais ou menos íntegra, ou uma recomposição đe elementos díspares? Por outras palavras: uma simples reinterpretação, ou também uma reconstrução?

Inicialmente, observemos que no terreno das fetividades religiosas de caráter dramático, coreográfico ou musical, as práticas mais ou menos ligadas a elementos de origem indígena são as que encontramos arraigadas no povo: cururu, dança de Santa Cruz, dança de São Gonçalo, folia do Divino. Se nas raízes dessa incorporação houvermos realmente de supor a atividade dos jesuítas, notemos que ela só foi coroada de êxito. quando propôs, à sociedade em formação, práticas que se pudessem ligar de modo mais ou menos direto às danças tupi. Assim foi que os 
autos sacros, tão caros ao esfồrço missionário de Anchieta, e expioracios por outros evangelizadores, não se implantaram e nem mesmo deixaram vestígio na vida festiva e religiosa do caipira paulista. E ao contrário, perduram até os nossos dias, tendo constituído a sua expressão mais corrente durante alguns siéculos, as práticas enumeradas acima, das quais a primeira, o cururu, é certamente a mais antiga, o vínculo entre tôdas e a mais diretamente arraigada na cultura tribal. ${ }^{48}$

Neste passo, a hipótese que proponho é a seguinte: o cururu significa, na sua forma primitiva, uma reinterpretação, e parcialmente reconstrução, de danças cerimoniais tupi. Quando os jesuítas criaram a dança de Santa Cruz, ligou-se a ela como complemento; o mesmo aconteceu ao se ajustar aqui a dança portuguêsa de São Gonçalo, cuja estrutura coreográfica sofreu influência marcada do cateretê; finalmente, já com certeza em pleno século XVIII, êle se ligou também à festa portuguêsa do Divino Espírito Santo. De maneira menos acentuada, ligou-se aos festejos juninos e do Natal, não coreográficos, nem musicais em si. O cururu se entrosa, portanto, no sistema total das festividades religiosas do caipira paulista, e, na ausência de documentos, êste fato basta como fiança da sua antigüidade e do significado profundo que tinha para êle. A hipótese levantada contém implicitamente a sugestão de que tal significado é devido à sua origem indígena, graças à qual pôde estabelecer ligação entre esta e a sociedade caipira, revelando as conexões de ambas no plano das representações e da afetividade.

A análise feita mais alto sugeriu que encontramos todos os elemen. tos constitutivos do cururu nas danças indígenas descritas pelos cronistas e modernamente pelos etnólogos, e, o que é mais importante, a recíproca é verdadeira. Nenhuma outra festividade paulista apresenta número tão elevado de traços coerentemente estruturados, cuja origem pode, sem dificuldade histórica, sociológica ou lógica, ser vinculada à cultura das tribos tupi; o próprio cateretê e a dança de caiapó não apresentam êste caráter de maneira tão nítida. Supondo-se que não provenha diretamente duma dança ritual do sapo, resta a conjetura alternativa (e mais prudente) de que é devido a uma reorganização dos referidos traços, por convergência. Assim teríamos um motivo plausível para explicar o fato de o cururu só ter aparecido - ou se desenvolvido - na área paulista: nela, e não em outras, ocorreram condições favoráveis à reorganização dos traços, graças a um sistema sócio-cultural em que se reinterpretaram funcionalmente valores fundamentais da cultura tupi. Caso o ocorrido fôsse a passagem de uma dança específica do sapo (o que, aliás, é possível), dificilmente poderíamos entender a sua delimitação geográfica.

O fato de ser o cururu uma dança nestas condições (com integração de elementos ameríndios funcionalmente reinterpretados) leva-nos a pensar na extensão real da intervenção jesuítica. Vimos que o fato de não ha- 
verem perdurado os seus aspectos mais puramente europeus - como a imposição do auto religioso - parece indicar, como sugeri, a existència de uma fôrça própria de organização na sociedade paulista tradicicnal. A intervenção jesuítica precisa, portanto, ser constantemente referida a essa "reação organizatória", para avaliarmos o seu real significado. E se o cururu representa de fato o que supõe a hipótese aqui levantada, teríamos a conclusão de que as práticas festivas mais características da cultura tradicional paulista foram as que não apenas inccrporaram os elementos religiosos, llinguísticos, poéticos e melódicos da cultura colonizadora, mas fizeram-no em ccnjugação com elementos estreitamente vinculados à cultura tribal do primitivo brasileiro - como foi o caso do cururu e do cateretê.

Note-se, aliás, que as práticas festivas de maior aceitação e permanência na cultura caipira são as carregadas de significado religioso mais ou menos vivo. Este significado foi um dos traços que asseguraram o desenvolvimento, nesta parte do mundo, de uma civilização tributária da ocidental - mas lembremos que êle se associou sempre a reminiscências da cultura tribal, que aparece dêste modo como condição do seu funcionamento na sociedade néo-brasileira de São Paujp.

5 .

Se encararmos, pois, as atividades lúdiccreligiosas do caipira paulista numa perspectiva temporal, encontraremos sempre, associado a elas, o cururu. Sendo o denominador comum, é provàvelmente a prática mais antiga e a que mais puramente lembrava ao índio catequizado e ao memeluco a vida tradicional da sua cultura de origem.

Intervindo na vida total do índio, a catequese interveio de modo acentuado na sua vida ritual e recreativa, procurando, como é notório, canalizá-la segundo os interêsses da ética e da religião impostas. Daí a substituição de danças e comemorações periódicas por outras tantas de tom cristão. Leia-se, a êste propósito, em Cardîm: "três festas celebram êstes índios com grande alegria, apleuso e gôsto particular. A primeira é a das fogueiras de São João, porque suas aldeias ardem em fogos, e para saltarem as fogueiras não os estorva a roupa, ainda que algumas vêzes chamusquem o couro. A segunda é a festa de ramos, porque é coisa para ver, as palmas, flores e boninas que buscam, a festa com que os têm nas mãos ao cfício, e procuram que lhes caia água benta nos ramos. A terceira que mais que tôdas festejam, é o dia de cinza, porque de ordinário nenhum falta, e do crbo do mundo vêm à cinza, e folgam que thes ponham grande cruz na testa, e se acontece o padre não ir às aldeias, por não ficarem sem cinza êles a dão uns aos outros." 49

Aí temos o caso de comemorações tradicionais incorporadas à vida do índio. Há, porém, o caso mais interessante de festas e danças origi- 
Não se creia, porém, que o sistema sócio-cultural de São Paullo fôsse do tipo missioneiro, ou paraguaio. A coexistência die culturas foi marcada, aqui, pela predominância dos padrões portuguêses, e sempre mais à medida que corriam os tempos. Os líderes da comunidade piratiningana, brancos ou mamelucos, falando embora língua-geral, usando arco-e-fle$x a$, comendo farinha de mandioca, curando-se com a flora aborígene, dansando cateretê, - tais líderes procuraram sempre manter a superimposição de cultura iniciada pelo jesuíta e o descobridor.

Daí decorre o que se poderia chamar, de um ponto de vista europeu, a depuração progressiva da sub-cultura caipira, acelerada no século XIX e já quase perfeita no atual, mas cujas raízes são velhas como o povoainento.

Continuando a tradição metropolitana, e por fôrça de ordenações, a Câmara de S. Paulo, como as demais, devia realizar, cada ano, as três festas do Corpo de Deus, da Visitação de Nossa Senhcra e do Anjo da Guarda, de comparecimento obrigatório a todos os moradores, sob pena de sanções legais. E quanto aos fclguedos de origem ameríndia, pelo menos alguns dêles eram severamente reprovados pela Câmara, estabelecendo-se que "todo homem cristão branco, que não fôsse negro de fora e se achasse em aldeia de negros forros cu cativos bebendo e bailando ao modo do dito gentio sofresse severa punição." 54

Desde o primeiro século, portanto, e apesar das condições propícias ao sincretismo, manifestava-se no Planalto, nitidamente, o antagonismo cultural. No entanto é preciso distinguir os aspectos por assim dizer oficializados da vida comemorativa e as manifestações verdadeiramente oficializadas da vida do povo. Esta conservou sempre, até os nossos dias, práticas oriundas da cultura aborígene, fundidas nas que provieram do dominador europeu. Não nos esqueçamos que em tôda a periferia de Piratininga, espalhavam-se as aldeias e vilas oriundas dos aldeamentos indígenas da catequese, e que foram o grande foco de tais práticas. A massa da população paulista, espraiada largamente pelo bandeirismo, participava sobretudo dêsse universo sincrético, não dos padrões preconizados pelos legisladores da Vila de São Paulo - dominantes, mas não exclusivos. À medida, porém, que marchava o tempo, os paulistas se incorporaram ao sistema geral do país e as cidades cresciam, a cultura caipira deixava cada vez mais os elementos indígenas em benefício dos europeus, e a vitória no longo processo veio afinal caber aos camaristas de mentalidade reinal. Enquanto tal não se dava, todavia, o cururu se formava e diferenciava, refletindo de algum modo a tensão cultural do meio planaltino.

Chegando a esta altura das considerações que venho fazendo, creio já ser possível esboçar um esquema final, sintetizando a sua formação e 
tado de pureza entre os tapuios da Amazônia, conservando-se inclusive a língua geral.

Suponho que o sairé ajuda a entrever a gênese do cururu.

$\mathrm{Na}$ primitiva zona paulista de colonização Serra-acima, - Piratininga e aldeias circundantes, como Santo Amaro, Embu, Itapecirica, Pitheiros, Carapicuíba, Barueri, Guarulhos, Itaquaquecetuba, Mogi - êle aparece, não isolado, mas como complemento das danças de Santa Cruz e São Gonçalo. Na zona em que se expandiu o povoamento, pelo vale do Tietê, a tradição mais antiga, e grande parte da realidade presente, mostram-no associado às comemorações de Santo Antônio, São João, São Pedro, Natal e Divino Espírito Santo. Parece, pois, que podemos interpretá-1o, sob êste aspecto, como o complemento, de origem ameríndia, que se ligou às comemorações provindas da cultura do colonizador. Comemorações mais prêsas aos seus padrões, como as últimas citadas, ou mais permeadas de elementos ameríndios, como as duas primeiras.

Segundo Oneyda Alvarenga, a dança de São Gonçalo, portuguêsa, e a de Santa Cruz, ligada mais frouxamente a costume português, foram, reelaborada uma, elaborada a outra, no processo da catequese, entroncando-se no cateretê. ${ }^{52}$ Em Anchieta e Fernão Cardim, vemos referida a festa tradicional da Santa Cruz, celebrada inteiramente à portuguêsa na Bahia, - como, aliás, se celebra ainda hoje por todo o Brasil no dia 3 de maio. ${ }^{53} \mathrm{Em}$ Piratininga, todavia, e área adjacente, e só aí, desenvolveu-se conjuntamente a dança respectiva, complementada pelo cururu. Na mesma zona, êle se ligou também à dança de S. Gonçalo, penetrada de elementos tupi.

Nestas duas danças, que têm estrutura regular, embora a segunda varie geogràficamente, o cururu foi complemento. Nos festejos, citados, mais impcrtantes do ponto de vista comemorativo, mas sem estrutura coreográfica e musical definida, ou apenas larvar no caso da festa do Divino, êle foi episódio culminante no que se refere ao aspecto lúdico.

6.

Enquanto o cateretê foi incorporado à cultura néo-brasileira por quase todo a país, o cururu parece ter ocorrido apenas em São Paulo e algumas das suas áreas de expansão. Condições especiais, já mencionadas, fizeram com que nesta área as práticas tradicionais portuguêsas só se integrassem na cultura popular mediante a mistura maior ou menor de elementos ameríndios; note-se, ainda, que a influência africana só veio a se exercer depois da fim do século XVIII, quando já se haviam estabelecido aqui as características, que ainda hoje encontramos, de uma sub-cultura bastante diferenciada, a caipira, levada pela difusão demo-cultural a grande parte dos atuais estados de Paraná, Minas, Goiás e Mato Grosso. 
nadas no processo da catequese pelo encontro das duas culturas em presença. Veja-se, por exemplo, entre os caboclos do Amazonas, o sairé, tão bem descrito por Barbosa Rodrigues. Atentemos bem às suas palavras, elucidativas do fenômeno que nos interessa: "Além da dança e do canto festivo têm os tapuios no dia de alguma festa religiosa, como a de S. Tomé, S. João ou Santo Antônio, um canto, antes uma saudação religiosa, introduzida nestas festas pelos missionários e chamada Sairé ou Turiua.

Esta é uma espécie de procissão de mulheres em que carregam o instrumento que tem o mesmo nome de sairé. Não faz por si a festa, mas, como disse, entra como uma saudação. A procissão dirige-se à Igreja, à casa do Juiz da festa, à do Vigário, etc., e aí as palavras não são as mesmas e sim próprias a quem se dirigem.

A palavra sairé deriva-se de çai e eré. "Salve! tu o dizes" ou saudação, e turiua, significa alegria ( ...)

(O) instrumento inventado pelos missicnários para perpetuar e firmar mais a religião entre os índios tem uma significação bíblica (...) O canto é sempre pela língua geral, e repetido em côro pelło mulherio (...) É o sairé a última tradição do tempo das missões dos Padres de Jesus." 50

$\mathrm{Na}$ descrição pormenorizada desta prática, por êle observada no Pará e no Amazonas no decênio de 1870, Barbosa Rodrigues conta que ela envolve danças de três dias, inclusive em frente ao altar, e cantos como o seguinte:

Purgatório porá etá

Uputare nomoessaua

Semué catú pahy,

Anhangá supeuara.

Upauana tecó puranga

Oike tecó pêssassu, .

Ianeara tecó ressé

Umumá tecó puranga.

O significado é: "Ensina-me, bom padre, rezas com que possamos salvar nossas almas do purgatório. A vida santa acabou-se, e por vontade do bom Deus entrou outra; isto é, a vida do trabalho. " 51

Devemos reter daí os seguintes traços: uma prática introduzida pelo catequizador em festas religiosas, como parte, ou complemento, envolvendo danças e cantos cuja palavras são de cunho didático e piedoso. Nctemos ainda que, dada a permanência de traços ponderáveis da culltura primitiva, (para não falar na raça), esta prática perdurou em es- 
posterior diferenciação. Dêste modo, ficarão respondidas, na medida do possível, as questões levantadas no início.

Das danças ameríndias, algumas passaram à cultura néo-brasileira, se não na sua integridade, em elementos que se incorporaram a danças portuguêsas, ou formadas aqui. Esta passagem se deu pello processo normal de difusão, ou foi, em certcs casos, dirigida pelo catequizador jesuíta com reinterpretação em têrmos religiosos. Tanto numa, quanto noutra, agiram as necessidades próprias da nova sociedade. (Enquanto o cateretê parece enquadrar-se nos dcis casos, sendo dança predominantemente profana, o cururu se prende mais ao segundo).

O cururu apresenta todos os traços descritos por Fernão Cardim, de maneira completa, e outros cronistas, fragmentàriamente, como característicos das danças tupi. Por outro lado, aparece ligado a tôdas as festas tradicionais que se incorporaram realmente à cultura popular na primitiva área de povoamento. Tudo leva a crer que seja uma dança formada pela convergência dos principais elementos das danças tupi, apresentando dêste modo um significado saliente para as populações néobrasileiras do Planalto. A hipótese da convergência, combinada à da intervenção jesuítica e do acentuado sincretismo lusorameríndio da cultura caipira, sugere uma explicação possível para o fato de só se haver desenvolvido em São Paulo.

O cururu deve ter sido incorporado como complemento da dança de Santa Cruz, aqui formada, e em seguida da de São Gonçalo, aqui reformada. De modo mais autônomo, incorporou-se também acs festejos populares de junho, de Pentecostes e do Natal, já aí, provàvelmente, menos por intervenção jesuítica do que por incorporação espontânea, propiciada pelo seu significado emocional para as popullações mamelucas. Este fato sugere a conjetura de que ocorresse também isolado, desde cêdo, como festejo-em-si. A êste título, é provável que tenha sofrido, posteriormente, influências de danças e cantos de origem portuguêsa, como o desafio à viola e a cana verde. Teríamos, então, o seguinte quadro:

Formação, por convergència, de uma dança encerrando de modo bastante completo os elementos característicos de danças tupi, e incorporando elementos religiosos do colonizador.

Justapõe-se, como complemento, às danças de Sta. Cruz e S. Gonçalo permeadas de elemen. tos ameríndios.
Incorpora-se, como ele. mento, a festejos tradicionais portuguêses in. cluidos na cultura popular: Santos de Junho, Divino, Natal.

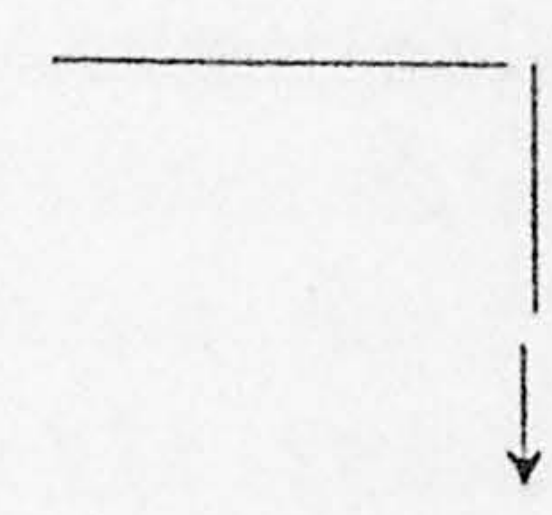

Manifesta-se independente, como dança reli. gioso-profana, menos importante que as outras modalidades e mais aberta a novas influências portuguêsas. 
Esta conclusão é hipotética, para não dizer conjectural, mas de modo algum fantasiosa. O atual cururu permite discernir, em tôdas as formas por que ocorre, elementos fundidos, cuja análise revela verdadeira sedimentação. Aplicando o critério tipológico, êstes elementos se polarizam em tôrno de alguns padrões básicos, que revelam a existência, no tempo, de mais de uma modalidade.

As três modalidades - cururu-complemento, cururu-elemento e cururu independente - devem ter se formado sucessivamente, e o seu destino se liga às próprias vicissitudes do povoamento planaltino. Quento ao primeiro, tudo leva a crer que só foi praticado na área piratiningana, cnde veio até os nossos dias como parte das duas velhas danças. Encontramos a segunda por tôda a zona tietêense e piracicabana, povocda no século XVIII, não havendo elementos para saber se floresceu noutras, de povoamento coevo (caminho do Anhangüera, caminho do Sul, área circundante de Itu) ou anterior (caminho do Rio de Janeiro). A área da terceira é a mesma, e não sabemos se antes ocorreu na da primeira.

Diante disto, não seria impossível concluir que a primeira modalidade foi também a mais importante, senão única a princípio, pois foi a que subsistiu na área de origem. A segunda ter-se-ia desenvolvido principalmente na área povoada dois séculos mais tarde, onde a dança exclusivamente religiosa não se difundiu, pois já a esta altura estava terminada a catequese. Tanto assim que a dança de S. Gonçalo nela se difundiu segundo outros moldes, disscciada do cururu. Este aparece aí sobretudo como elemento dos festejos mencionados mais alto.

O fato de ccorrer em Mato Grosso e Goiás sobretudo a terceira modalidade, ela sugere que no século XVIII ocorriam não apenas na área tietêense - de onde partiam as monções para a primeira capitania mas na piratiningana, onde se radicava o caminho para a segunda. Como quer que seja, a primitiva área de catequese viu florescer a primeira modalidade até os nossos dias; as duas seriam de aparecimento tardio e talvez nunca muito importante, tendonse afinal extinguido. Nas outras áreas em que se expandiu o povoamento piratiningano, encontramos a segunda e a terceira modalidadie na $z \subset n a$ tietêense-piracicabana, a terceira em Mato Grosso e Goiás. Mais do que sugerimos, seria difícil sugerir, sem cair na fantasia.

\section{NOTAS}

(1) Poesia Popular e Mudança Social, em elaboração.

(2) Andrade, 1942, p. 146.

(3) Geraldo Brandão, estudando a dança de S. Gonçalo, mas abordando também a de Sta. Cruz e o cururu, discute com pertinência alguns aspectos dêste problema, procurando levar em conta não apenas a herança indigena, como a portuguêsa, cujo interrelacionamento intimo sugere. (v. Brandão, 1953.)

(4) Beaurepaire-Rohan, 1889. Ver Martius, 1867, p. 44. 
(5) Ver, respectivamente: Nordenskiöld, 1912, p. 219-222 e Métraux, 1948 b, p. 484; Nimuendajú, 1944, p. 32; Baldus, 1931, p. 213-214; Baldus, 1937, p. 215; Baldus, 1936, p. 755; Métraux, 1948-a, p. 438; Snethlage, ap. Baldus, 1931, p. 213-214 e 1937, p. 215-216; Baldus, 1952, p. 484-485.

(6) Ver, respectivamente, Nordenskiöld, cit., loc. cit., e Métraux, 1948-b, loc. cit., Nordenskiöld, cit., p. 266.

(7) Métraux, 1948-a, p. 448; Baldus, 1937, p. 200-201 e 212.

(8) Baldus, 1937, p. 212-213 e tb. 1931, p. 213. Do primeiro estudo parti para quase tôdas as referências acima.

(9) Baldus, 1937, pp. 213-216 e 1931, p. 213-214.

(10) Barbosa Rodrigues, 1886-7, p. 315.

(11) Ribeiro, 1919, p. 230.

(12) Colbacchini e Albisetti, 1942, pp. 395-396.

(13) Schmidt, 1942, p. 109-110, 114-117, 123 (V. Métraux, 1946, p. 418); Döppenschmidt, 1951, p. 107-108.

Note-se que entre os Guató apresenta cunho puramente recreativo; entre os Kinikinau está ligado a acentuados elementos religiosos, mostrando a dissociação funcional que se pode verificar no processo de difusão de cultura.

(14) V. Sílvio Romero, 1883, I, p. 132: “(...) Êstes versinhos creio que são cantados e dançados, pois são precedidos dêstes: "Sapateiro novo /me faz um sapato/ de sola bem fina/ pr'a dançar o sapo". A quadra foi colhida em Sergipe. Seria uma reminiscência de dança dêste tipo?

(15) V. discussão recente do problema em Schaden, 1954 , § IV, que pende para a hipótese plausivel de os Guaianá serem Tupiniquim.

(16) Métraux, 1946, p. 446.

(17) Carta de Nóbrega ao P. Simão Rodrigues, julho de 1552, em Leite, 1940, p. 29-30. Anchieta, 1933, p. 478. Cardim, 1939, p. 270.

(18) Nóbrega, cit., p. 32.

(19) Esta reflexão não se refere, é claro, à política desenvolvida nas Missões do Sul e do Paraguai, mas à catequese do Brasil.

(20) Cardim, ob. cit., p. 258.

(21) Idem, p. 271.

(22) Idem, p. 300.

(23) V. Confissões da Bahia, 1935, p. 28-29, 78-80, 87-89, 104-107, e sobretudo 167-173, bem como as reflexóes de Capistrano de Abreu no "Prefácio", XVIII-XIX. Notem-se dois tipos de apropriação do carisma por parte do catecúmeno: no caso da Santidade, - em que o ex-aluno dos jesuítas batiza - há uma espécie de concorrência heterodoxa à atividade do padre; no do exemplo abaixo há refôrço da catequese: “( . . ) e se acontece o padre não ir às aldeias, por não ficarem sem cinza êles a dão uns aos outros, como aconteceu a uma velha que, faltando o padre, convocou tôda a aldeia à igreja e thes deu a cinza, dizendo que assim fariam os Abarés, sc. padres, e que não haviam de ficar em tal solenidade sem cinza." (Cardim, cit., p. 280).

(24) Leite, 1938, II, p. 102-103. Cfr. Couto de Magalhães, 1935, p. 317: “ $\because$ a (dança) brasileira, essencialmente paulista, mineira e fluminense, é o cateretê, tão profundamente honesta (era dança religiosa entre os tupis) que o padre Joseph de Anchieta a introduziu nas festas de Sta. Cruz, São Gonçalo, Espírito Santo, São João e Senhora da Conceição, compondo para elas versos em tupi, que existem até hoje e de que possuo cópia”.

(25) "Na verdade, entre a vida americana e o cristianismo, que principiava, era mister uma ponte". Leite, 1938, p. 12. 
(26) "Arremedam pássaros, cobras, e outros animais, tudo trovado por comparações”. Cardim, ob. cit., pág. 271. "Além desta celebram os mundurucús outras festas no correr do ano, mas nao guerreıras: sao as festas dos animais (...) Depois de uma grande caçada fazem grandes danças em que arremedam a voz dos animais que festejam". "... cantam e dansam (os Pariqui) várias peças, que, tôdas no canto mostram costumes de animais, assim como as danças arremedam o seu viver (...), tendo cada animal o seu canto mais ou menos variado, mas sempre suave e harmonioso, tendo alguns semelhança com as nossas modinhas". "Nestas danças (os Tembé) imitam os costumes do animal que representam caçar". Barbosa Rodrigues, 1881, págs. 43-52-53 e 50. Tôdas as tribos citadas são do grupo lingüístico Tupi .

(27) Léry, 1880, II, p. 70.

(28) Cardim, 1939, p. 154.

(29) Soares de Sousa, 1851, p. 324.

(30) Métraux, 1946, p. 468-9.

(31) Barbosa Rodrigues, 1881, p. 49; Nimuendaju, 1948, p. 319.

(32) Léry, 1880, II, p. 71-72.

(33) Soares de Souza, 1851, p. 324.

(34) Cardim, 1939, p. 155.

(35) Wagley and Galvão, 1948b, p. 175 e 1948a, p. 143.

(36) Cardim, 1939, p. 271.

(37) Cardim, 1939 , p. 312 e 300 . O primeiro passo é referente a São Paulo, o segundo ao Espírito Santo.

(38) Anchieta, 1948 e 1950.

(39) Métraux, 1946, p. 468.

(40) Cardim, 1939, pág. 155.

(41) Soares de Souza, 1851, p. 324.

(42) Wagley and Galvão, 1948b, p. 174.

(43) Idem, 1948a, p. 144.

(44) Staden, 1942, p. 132-133. Cp. Thevet, 1878, p. 178.

(45) Salvador, s/d, p. 53.

(46) Cardim, cit., p. 272.

(47) Anchieta, 1933, p. 433.

(48) "Possivelmente Cururu venha da deturpação do vocábulo "Cruz", que o gentio pronunciava "curuce", "curu". A repetição da última sílaba é bem do sabor das línguas primitivas. E, como dança catequizadora, era realizada diante da cruz". (Maynard de Araujo, 1952, pág. 23) Se tal hipótese fôsse possível, teríamos um indício seguro para o esclarecimento do problema. Os especialistas do Departamento de Etnografia Brasileira e Língua Tupi-Guarani da Universidade de São Paulo, consultados, informam. me todavia ser improvável a derivação sugerida.

(49) Cardim, ob. cit., p. 280.

(50) Barbosa Podrigues, 1881, p. 56, 57 e 59. Também 1890, p. 279-286.

(51) Barbosa Rodrigues, 1881, p. 58.

(52) Alvarenga, $1950, \mathrm{p} .206-7$.

(53) Anchieta, 1933, p. 396.

(54) Taunay, São Paulo, nos primeiros anos, apud Ribeiro, 1946, p. 113-114. O citado ato da Câmara é de 19 de janeiro de 1583. As festas reprovadas chamavam-se genèricamente tapuiadas. 
Alvarenga, Oneyda

1950 - Música Popular Brasileira, Editora Globo, Porto Alegre.

Anchieta, José de

1933 - Cartas, Informacões, Fragmentos Históricos e Sermões do Padre ( ) (1554-1584), Civilização Brasileira S. A., Rio de Janeiro.

1948 - Auto representado na festa de São Lourenço, Peça trilingue do séc. XVI, transcrita, comentada e traduzida, na parte tupi, por M. L. de Paula Martins, São Paulo.

1950 - Na vila de Vitória e na Visitação de Santa Isabel, Peças em castelhano e português, do séc. XVI, transcritas e comentadas por I. L. de Paula Martins, São Paulo.

Andrade, Mário de

1942 - Pequena História da Música, 2. a edição, Livraria Martins, São Paulo.

Baldus, Herbet

1931 - Indianerstudien im Nordöstlichen Chaco, C. L. Hirschfeld Verlag, Leipzig.

1936 - "Ligeiras notas sôbre duas tribus tupis da margem paraguaia do Alto Paraná”, Revista do Museu Paulista, XX, São Paulo, p. 479-756.

1937 - Ensaios de Etnologia Brasileira, Brasiliana, vol. 101, Companhia Editora Nacional, São Paulo.

1952 - "Breve notícia sôbre os Mbyá-Guarani de Guarita", Revista do Museu Paulista, Nova Série, VI, São Paulo, p. 484-485.

Barbosa Rodrigues, João

1881 - "O canto e dança selvícola", Revista Brasileira, IX, Rio de Janeiro, p. 32-60.

1886-7 - "Poranduba Amazonense", Anais de Biblioteca Nacional XIV, $2 .^{\circ}$, Rio de Janeiro.

Beaurepaire-Rohan, Tenente General Visconde de

1889 - Dicionário de Vocábulos Brasileiros, Imprensa Nacional, Rio de Janeiro.

Brandão, Geraldo

1953 - Notas sôbre a dança de São Gonçalo do Amarante (sem menção. de lugar ou editor).

Capistrano de Abreu, J., ed.

1935 - Primeira Visitação do Santo Ofício às Partes do Brasil pelo Licenciado Heitor Furtado de Mendoça, etc. Confissões da Bahia, 1591-92, com Prefácio de J. Capistrano de Abreu, Edição da Sociedade Capistrano de Abreu, Rio de Janeiro.

Cardim, Fernão

1939 - Tratados da Terra e Gente do Brasil, Introdução e notas de Baptista Caetano, Capistrano de Abreu, Rodolfo Garcia, Brasiliana, vol. 168, Companhia Editora Nacional, São Paulo.

Colbacchini, P. Antonio, e Albisetti, P. Cesar

1942 - Os Boróros Orientais Orarimogodógue do Planalto Oriental de Mato Grosso, Brasiliana, Série Grande Formato, vol. 4, Companhia Editora Nacional, São Paulo.

Couto de Magalhães, General

1935 - O Selvagem, 3.a edição completa, Brasiliana, vol., 52, Companhia Editora Nacional, São Paulo, 1935. 
Döppenschmidt, Edmund

1951 - "Weihnachten bei den Kinikináus-Indianern", Serra-Post Kalender, Ijui, p. 99-110.

Leite, Serafim

1938 - História da Companhia de Jesus no Brasil, Tomo II (Século XVI - A Obra), Livraria Portugalia, Lisboa.

1940 - Novas Cartas Jesuiticlas (De Nóbrega a Vieira), Brasiliana, vol. 194, Companhia Editora Nacional, São Paulo.

Léry, Iean de

1880 - Histoire d'un Voyage fait en la terre du Brésil, Nouvelle édition avec une introduction et des notes de Paul Gaffarel, Alphonse Lemerre, Editeur, Paris, 2 vols.

Martius, Carl Friedrich Phil. von

1867 - Wörtersammlung Brasilianischer Sprachen, Friedrich Fleischer, Leipzig.

Maynard de Araújo, Alceu

1952 - Documentário Folclórico Paulista, Prefeitura de São Paulo, Departamento de Cultura, Divisão do Arquivo Histórico, São Paulo.

Métraux, Alfred

1946 - "The Caingang", Julian Steward, Editor, Handbook of South American Indians, volume 1, The Marginal Tribes, Washington, p. 445-506.

$1948 \mathrm{a}$ - "The tribes of Eastern Bolivia and the Madeira Headwaters" Idem, volume 3, The Tropical Forest Tribes, p. 381-454.

$1948 \mathrm{~b}$ - "Thet ribes of the eastern slopes of the Bolivian Andes", Idem, Ibidem, p. 465-506.

Nimuendajú, Curt

1944 - Leyenda de la creación y juigio final del mundo como fundamento de la religión de los Apapokuva-Guarani, Tradução de Juan Francisco Recalde, Edição mimeografada, S. Paulo.

1948 - "The Cayabí, Tapanyuna, and Apiacá". Handbook of South American Indians, Vol. 3, p. 307-320.

Nordenskiöld, Erland

1912 - "La vie des indiens dans le Chaco", Revue de Géographie, VI, fasc. III, Librarie Ch. Delagrave, Paris, p. 1-278.

Ribeiro, João

1919 - Folk-Lore (Estudos de literatura popular), Jacinto Ribeiro dos Santos, Rio de Janeiro.

Ribeiro, Joaquim

1946 - Folklore dos Bandeirantes, Coleção Documentos Brasileiros, vol. 53, Livraria José Olympio Editora, Rio de Janeiro.

Romero, Sylvio

1883 - Cantos Populares do Brasil, acompanhados de introdução e notas comparativas por Theophilo Braga, Nova Livraria Internacional Editora, Lisboa, 2 volumes.

Salvador, Frei Vicente do

s.d. - História do Brasil, 3. a edição revista por Capistrano de Abreu e

Schaden, Egon

$$
\text { Rodolpho Garcia, Comp. Melhoramentos de São Paulo. }
$$

1954 - "Os primitivos habitantes do território paulista", O Estado de São Paulo, Edição do IV Centenário.

Schmidt, Max

1942 - Estudos de Etnologia Brasileira, Peripécias de uma viagem en- 
tre 1900 e 1901. Seus resultados etnológicos. Tradução de Catarina Baratz Canabrava, Brasiliana, Série Grande Formato, vol. 2, Companhia Editora Nacional, São Paulo.

Soares de Sousa, Gabriel

1851 - Tratado descritivo do Brasil etc., edição ... por Francisco Adolpho de Varnhagen, Typographia Universal de Laemmert,

Staden, Hans Rio de Janeiro.

1942 - Duas Viagens ao Brasil etc., Transcrito em alemão moderno por Carlos Fouquet e traduzido dêsse original por Guiomar de Carvalho Franco, com uma introdução e notas de Francisco de Assis Carvalho Franco, Publicaçoes da Sociedade Hans Staden,

Thevet, André Sào Paulo.

1878 - Les Singularitez de la France Antarctique, nouvelle édition avec notes et commentaires par Paul Gaffarel, Maisonneuve \& Cie., Paris .

Wagley, Charles, and Galvão, Eduardo

1948 a- "The Tenetehara", Handbook of South American Indians, vol. 3, p. 137-148.

1948b- "The Tapirapé", Handbook of South Americans Indians, vol. 3, p. 167-177. 